\title{
Chicken meat quality: genetic variability and relationship with growth and muscle characteristics
}

\author{
Elisabeth Le Bihan-Duval ${ }^{* 1}$, Martine Debut ${ }^{1}$, Cécile M Berri ${ }^{1}$, Nadine Sellier ${ }^{1}$, \\ Véronique Santé-Lhoutellier ${ }^{2}$, Yves Jégo ${ }^{3}$ and Catherine Beaumont ${ }^{1}$
}

Address: ${ }^{1}$ Institut National de la Recherche Agronomique (INRA), UR83 Recherches Avicoles, F-37380 Nouzilly, France, ${ }^{2}$ INRA, UR370 Qualité des Produits Animaux, F-63122 Saint-Genès-Champanelle, France and ${ }^{3}$ Hubbard, F-35220 Châteaubourg, France

Email: Elisabeth Le Bihan-Duval* - Elisabeth.Lebihan@tours.inra.fr; Martine Debut - mdebut@interporcra.fr;

Cécile M Berri - Cecile.Berri@tours.inra.fr; Nadine Sellier - Nadine.Sellier@tours.inra.fr; Véronique Santé-Lhoutellier - vero@clermont.inra.fr; Yves Jégo - yves.jego@ hubbardbreeders.com; Catherine Beaumont - Catherine.Beaumont@tours.inra.fr

* Corresponding author

Published: 18 August 2008

BMC Genetics 2008, 9:53 doi:10.1/86//47/-2156-9-53
Received: 27 February 2008

Accepted: 18 August 2008

This article is available from: http://www.biomedcentral.com/I47I-2/56/9/53

(c) 2008 Le Bihan-Duval et al; licensee BioMed Central Ltd.

This is an Open Access article distributed under the terms of the Creative Commons Attribution License (http://creativecommons.org/licenses/by/2.0), which permits unrestricted use, distribution, and reproduction in any medium, provided the original work is properly cited.

\begin{abstract}
Background: The qualitative properties of the meat are of major importance for poultry breeding, since meat is now widely consumed as cuts or as processed products. The aim of this study was to evaluate the genetic parameters of several breast meat quality traits and their genetic relationships with muscle characteristics in a heavy commercial line of broilers.

Results: Significant levels of heritability (averaging 0.3 ) were obtained for breast meat quality traits such as $\mathrm{pH}$ at 15 min post-slaughter, ultimate $\mathrm{pH}(\mathrm{pHu})$, color assessed by lightness $\mathrm{L}^{*}$, redness a* and yellowness $b^{*}$, drip loss, thawing-cooking loss and shear-force. The rate of decrease in $\mathrm{pH}$ early post-mortem and the final $\mathrm{pH}$ of the meat were shown to be key factors of chicken meat quality. In particular, a decrease in the final $\mathrm{pH}$ led to paler, more exudative and tougher breast meat. The level of glycogen stored in breast muscle estimated by the Glycolytic Potential (GP) at slaughter time was shown to be highly heritable $\left(h^{2} 0.43\right)$. There was a very strong negative genetic correlation $(\mathrm{rg})$ with ultimate meat $\mathrm{pH}(\mathrm{rg}-0.97)$, suggesting a common genetic control for $\mathrm{GP}$ and $\mathrm{pHu}$. While breast muscle weight was genetically positively correlated with fiber size ( $\mathrm{rg} 0.76)$, it was negatively correlated with the level of glycogen stored in the muscle ( $\mathrm{rg}-0.58)$, and as a consequence it was positively correlated with the final pH of the meat $(\mathrm{rg} \mathrm{0.84})$.
\end{abstract}

Conclusion: This genetic study confirmed that selection should be useful to improve meat characteristics of meat-type chickens without impairing profitability because no genetic conflict was detected between meat quality and meat quantity. Moreover, the results suggested relevant selection criteria such as ultimate $\mathrm{pH}$, which is strongly related to color, water-holding capacity and texture of the meat in this heavy chicken line.

\section{Background}

As in other animal species, the technological quality of poultry meat is now of major importance, since poultry meat is nowadays usually consumed as cuts or as proc- essed products rather than as whole carcasses. As already reported for pigs [1], technological quality refers to several meat properties, including water-holding capacity (i.e. drip loss during storage), intensity and homogeneity of 
color, firmness, shelf-life and processing yields. Meat quality is closely related to the decrease in muscle $\mathrm{pH}$ post-mortem. Rapid postmortem decline in $\mathrm{pH}$ (evidenced by low $\mathrm{pH}$ value measured $15 \mathrm{~min}$ post-slaughter in poultry, i.e. pH15) results in PSE (pale, soft, exudative) meat with a pale aspect and reduced water-holding capacity $[2,3]$. Variations in the extent of decrease in $\mathrm{pH}$ are also responsible for variations in meat quality. Low ultimate $\mathrm{pH}$ (measured $24 \mathrm{~h}$ post-slaughter in poultry) results in "acid meat", with similar defects to those of PSE meat [4], while high ultimate $\mathrm{pH}$ leads to DFD (dark, firm, dry) meat with dark color and poor storage quality [5]. In pigs, the PSE meat and "acid meat" defects have been shown to be controlled by major genes [1], i.e. halothane sensitivity $[6]$ and $\mathrm{RN}[7,8]$ genes, respectively.

The inclusion of meat quality in pig breeding schemes dates back to the 1970-1980s [1]. Varying emphasis has been given to traits of interest according to country such as meat color (certainly the most widely used quality indicator), $\mathrm{pH}$ and intramuscular fat content. Genetic studies on meat quality traits in poultry are more recent. Quite significant levels of heritability (ranging from 0.35 to 0.57 ) were obtained for meat $\mathrm{pH}$, color and water-holding capacity in two studies conducted on the same experimental broiler line slaughtered under experimental conditions $[9,10]$. More moderate heritability values (ranging from 0.12 to 0.22 ) were reported for the same meat traits measured in turkeys slaughtered under commercial conditions [11]. A study performed in quails [12] also reported moderate to high levels of heritability $(0.22-0.48)$ of ultimate meat $\mathrm{pH}$ and color indicators. The present study reports the first evaluations of genetic parameters of meat quality traits and their genetic correlations with growth and muscle characteristics in a commercial broiler line.

\section{Results}

Descriptive statistics for growth and body composition traits and for muscle and meat characteristics are summarized in Table 1. Distributions of these traits were close to normality, except for drip loss (DL) for which slight asymmetry was observed (data not shown).

\section{Heritability estimates}

As shown in Table 1, the heritability for growth and body composition traits was moderate to high (estimates ranging from 0.30 to 0.49 ) in this pure broiler line. Muscle characteristics such as fiber cross section area (CSA) and GP exhibited high levels of heritability (over 0.40 ). The traits related to decrease in $\mathrm{pH}$ post-mortem (i.e. lactate, pH15 and pHu) and to meat quality (color, water retention, texture) were significantly heritable, with heritability values ranging from 0.25 to 0.35 .

\section{Genetic correlation estimates}

This study revealed a strong genetic association between breast muscle GP and $\mathrm{pHu}$, with an estimated genetic correlation of $-0.97 \pm 0.03$. Lactate concentration and $\mathrm{pH} 15$ were also highly negatively correlated ( $\mathrm{rg}-0.88 \pm 0.05)$. In contrast, the rate and extent of decrease in $\mathrm{pH}$ appeared to be genetically independent, since pH15 and pHu exhibited a genetic correlation of $-0.05 \pm 0.24$.

As summarized in Table 2, post-mortem muscle metabolism traits were significantly genetically related to meat quality traits. In particular, pHu exhibited significant neg-

Table I: Descriptive statistics and heritability estimates for body weight, body composition, muscle characteristics and meat quality traits.

\begin{tabular}{|c|c|c|c|c|c|}
\hline Traits & $\mathbf{N}$ & Mean \pm SD & Min. & Max. & $h^{2} \pm S E$ \\
\hline \multicolumn{6}{|l|}{ Growth and body composition } \\
\hline Body weight at 6 weeks $(g)$ & 592 & $2|4| \pm 326$ & 1234 & 3028 & $0.49 \pm 0.06$ \\
\hline Weight gain from 4 to 6 weeks (g) & 596 & $1040 \pm 229$ & 357 & 1646 & $0.30 \pm 0.05$ \\
\hline Pectoralis major muscle weight $(\mathrm{g})$ & 578 & $148.6 \pm 28.4$ & 53.0 & 231.9 & $0.38 \pm 0.06$ \\
\hline Breast muscle yield $(\%)$ & 580 & $17.8 \pm 1.5$ & $1 \mathrm{l} .4$ & 22.4 & $0.30 \pm 0.04$ \\
\hline Abdominal fat (\%) & 583 & $2.6 \pm 0.6$ & 0.6 & 4.6 & $0.48 \pm 0.06$ \\
\hline \multicolumn{6}{|l|}{ Muscle characteristics } \\
\hline Fiber Cross Section Area $\left(\mu \mathrm{m}^{2}\right)$ & 592 & $|83| \pm 426$ & 630 & 3157 & $0.41 \pm 0.06$ \\
\hline Lactate ( $\mu \mathrm{mol} / \mathrm{g}$ muscle) & 596 & $33.1 \pm 10.0$ & 6.3 & 56.9 & $0.27 \pm 0.05$ \\
\hline $\mathrm{pH} 15$ min post-mortem (pHI5) & 599 & $6.45 \pm 0.13$ & 6.02 & 6.79 & $0.30 \pm 0.05$ \\
\hline Glycolytic Potential ( $\mu \mathrm{mol} / \mathrm{g}$ muscle) & 591 & $108.0 \pm 17.7$ & 70.0 & 167.2 & $0.43 \pm 0.05$ \\
\hline Ultimate $\mathrm{pH}(\mathrm{pHu})$ & 587 & $5.64 \pm 0.12$ & 5.35 & 6.04 & $0.34 \pm 0.06$ \\
\hline \multicolumn{6}{|l|}{ Meat quality traits } \\
\hline Lightness $\left(L^{*}\right)$ & 590 & $54.9 \pm 3.0$ & 42.6 & 63.7 & $0.35 \pm 0.05$ \\
\hline Redness $\left(\mathrm{a}^{*}\right)$ & 587 & $-0.8 \pm 0.7$ & -2.8 & 1.3 & $0.25 \pm 0.05$ \\
\hline Yellowness (b*) & 590 & $11.8 \pm 1.6$ & 8.2 & 16.8 & $0.31 \pm 0.06$ \\
\hline Drip loss (DL, \%) & 589 & $1.6 \pm 1.0$ & 0.0 & 6.2 & $0.26 \pm 0.04$ \\
\hline Thawing-cooking loss (TCL, \%) & 581 & $14.6 \pm 4.8$ & 3.1 & 28.6 & $0.35 \pm 0.05$ \\
\hline Warner Bratzler shear force (WB, N/cm²) & 570 & $14.5 \pm 3.0$ & 5.9 & 25.5 & $0.34 \pm 0.05$ \\
\hline
\end{tabular}


ative genetic correlation with meat lightness and yellowness ( $\mathrm{rg}-0.65 \pm 0.11$ and $-0.54 \pm 0.11$, respectively), and even more marked negative correlation with meat drip loss, thawing-cooking loss and Warner Bratzler shear force (rg -0.80). As expected, opposite and somewhat less pronounced genetic correlations were found between meat quality traits and muscle GP. Muscle pH15 was mainly related to lightness and drip loss of meat ( $\mathrm{rg}-0.52 \pm 0.10$ and $-0.55 \pm 0.10$, respectively).

Body and breast muscle weights appeared to be significantly related to fiber size, with positive genetic correlations of $0.69 \pm 0.08,0.76 \pm 0.06$ and $0.48 \pm 0.09$ between fiber CSA and weight gain (between 4 and 6 weeks), breast muscle weight and breast muscle yield, respectively. Interestingly, breast muscle weight exhibited a significantly negative genetic relationship with muscle GP ( $\mathrm{rg}-0.58 \pm$ $0.11)$, and in turn a positive correlation with $\mathrm{pHu}(0.84 \pm$ 0.07 ). Significantly negative genetic correlations were also found between breast muscle mass and lightness ( $\mathrm{rg}-0.55$ $\pm 0.10)$, drip loss $(-0.65 \pm 0.10)$, thawing-cooking loss ($0.80 \pm 0.06)$ and Warner Bratzler shear force $(-0.60 \pm$ $0.10)$.

\section{Discussion}

For the first time in a commercial broiler line, this study evaluated both the contribution of genetics to variations in meat quality traits and the genetic correlations with muscle characteristics such as fiber size and glycogen content. Quite significant levels of heritability were evidenced for meat properties such as thawing-cooking loss that can affect the processability of meat, and color and toughness that can influence the sensorial quality of meat. These genetic results emphasized the importance of the decrease in muscle $\mathrm{pH}$ post-mortem for breast meat quality in poultry. They indicated that, as for pigs [1], the final $\mathrm{pH}$ has an extensive effect on the water-holding capacity, color and texture of raw and cooked meat, while the early decrease in pH mainly influences the drip loss and lightness $\left(\mathrm{L}^{*}\right)$ of raw meat, at least in this genotype. Selection for a lower final $\mathrm{pH}$ would lead to a higher incidence of pale and exudative meat that is tough after cooking and not very appropriate for industrial processing. On the other hand, selection for a higher final $\mathrm{pH}$ could improve the processing yield but could also affect storage and sen- sorial quality because of negative influences on microbial development and juiciness of the meat [5]. Ultimate $\mathrm{pH}$, lightness and drip loss of meat were introduced into the French national breeding program for pigs in the 1980s, forming a combined quality index. It has been maintained constant across the generations of selection.

The strong negative genetic correlation between glycogen content of breast muscle (estimated through the glycolytic potential) and ultimate $\mathrm{pH}$ represents a major result in the present study. The genetic control of glycolytic potential and its genetic relationships with meat quality have been more widely studied in pigs than in poultry. Genetic studies in pigs have focused on either post-mortem glycolytic potential (PMGP), as for the present study, or on in vivo glycolytic potential (IVGP) obtained from muscle biopsy on live animals (which is not yet available for the chicken). In pigs, fairly negative genetic correlations (ranging from -0.74 to -0.99) have been reported between PMGP and pHu measured on the same muscle or on different muscles with close metabolic characteristics [13]. Corresponding correlations were slightly lower when IVGP was considered [13]. Heritability values for IVGP were around 0.25 in a population of pigs without the $\mathrm{RN}^{-}$ allele [13], while an average value of 0.21 was reported for $\mathrm{pHu}$ [1]. These genetic results together demonstrated that GP and pHu have close genetic control, and that in poultry, as in pigs, both traits can be modified by selection. In agreement with a previous genetic study in an experimental broiler line [10], the present study indicated that the rate and the extent of decrease in $\mathrm{pH}$ post-mortem are under the control of different genes. A similar conclusion was drawn from a selection experiment in pigs, in which a very low genetic correlation was found between IVGP and $\mathrm{pH}$ measured $30 \mathrm{~min}$ post-mortem [14]. In the chicken, the rate of decrease in $\mathrm{pH}$ was shown to be influenced by behavior at slaughter and hastened by struggle activity of the birds on the shackle line, especially wing flapping [15]. However, little is known to date about the influence of genetics on such behavioral traits and the implications for meat quality.

By estimating the genetic correlations, this study made it possible to correlate responses on muscle and meat quality traits with selection on growth and breast development

Table 2: Estimated genetic correlations between post-mortem muscle characteristics and meat quality traits.

\begin{tabular}{ccccccc}
\hline Meat traits & Lightness $\left(\mathrm{L}^{*}\right)$ & Redness $\left(\mathrm{a}^{*}\right)$ & Yellowness $\left(\mathrm{b}^{*}\right)$ & Drip Loss & Thawing-cooking loss & Warner Bratzler shear force \\
\hline Lactate & $0.28 \pm 0.16$ & $0.36^{* *} \pm 0.08$ & $0.41^{* *} \pm 0.11$ & $0.54^{* *} \pm 0.04$ & $0.20 \pm 0.10$ & $0.36^{* *} \pm 0.07$ \\
pHI5 & $-0.52^{* *} \pm 0.10$ & $-0.02 \pm 0.15$ & $-0.16 \pm 0.18$ & $-0.55^{* *} \pm 0.10$ & $-0.19 \pm 0.10$ & $-0.24 \pm 0.14$ \\
Glycolytic Potential & $0.52^{* *} \pm 0.07$ & $0.51^{* *} \pm 0.11$ & $0.60^{* *} \pm 0.10$ & $0.78^{* *} \pm 0.04$ & $0.49^{* *} \pm 0.10$ & $0.52^{* *} \pm 0.05$ \\
pHu & $-0.65^{* *} \pm 0.11$ & $-0.35^{* *} \pm 0.13$ & $-0.54^{* *} \pm 0.11$ & $-0.89^{* *} \pm 0.05$ & $-0.80^{* *} \pm 0.10$ & $-0.8 I^{* *} \pm 0.06$ \\
\hline
\end{tabular}

I Lactate $=$ Lactate concentration 15 min post-slaughter; $\mathrm{pHI} 5=\mathrm{pH}$ measured 15 min post-slaughter; $\mathrm{pHu}=$ Ultimate $\mathrm{pH}$.

** Genetic correlation is significantly different from zero $(p<0.0 \mathrm{I})$. 
applied in meat-type chicken. These results indicated that selection for increased breast muscle mass is expected to lead to greater fiber hypertrophy, since a strong positive genetic correlation was observed between both traits. This was in agreement with previous results obtained by comparing experimental chicken lines divergently selected for growth [16], or differing in breast yield [17]. Most studies in pigs have indicated that selection for lean growth is associated with increases in both fiber size and number [18]. The extent to which fiber number can be modified to increase breast muscle mass in the chicken has still to be investigated. Our original results also indicated that (at least in this meat-type strain) selection for increased growth and breast muscle mass can be expected to reduce glycogen storage and in turn to increase ultimate breast meat $\mathrm{pH}$. Similar results have been reported at the phenotype level, when experimental and commercial chicken lines selected for increased body weight and breast yield were compared to their respective unselected control lines [19]. Inverse relationships have been reported in pigs, for which carcass leanness appeared to be moderately positively correlated with muscle GP and negatively with $\mathrm{pHu}$ $[13,1]$. This suggests that physiological and genetic factors involved in the control of GP and pHu could be at least partly different between pigs and poultry.

\section{Conclusion}

Meat quality homogeneity has become a major concern for the poultry market. This genetic study confirmed that selection could be valuable to improve meat characteristics. The major factors contributing to meat quality were heritable, and no genetic conflict was detected between meat quality and meat quantity. Furthermore, the present results suggest that the ultimate $\mathrm{pH}$ of meat is a relevant selection criterion since it was strongly related to meat color, water-holding capacity and texture. More research is now needed to define the optimal breeding strategy to improve meat quality, which could be based either on classical polygenic selection or on the use of molecular markers. The first Quantitative Trait Loci (QTL) of meat quality traits were recently identified in a cross between experimental chicken lines divergently selected for growth [20]. Such research has now to be extended to commercial flocks, in order to identify effective molecular tools for selection on poultry meat quality.

\section{Methods}

\section{Animals, Rearing and Slaughtering Conditions}

This genetic analysis was conducted on 312 male and 293 female pedigree birds, which were the progeny of 15 sires and 64 dams. The birds originated from a male grand-parent line intensively selected for growth and breast muscle yield, and currently used by Hubbard (Chateaubourg, France) to produce parent males. As described in detail by Berri et al. [21], birds were reared in two successive batches under regular conditions in a conventional poultry house at the INRA Experimental Poultry Unit (Nouzilly, France). Birds were given ad libitum access to a standard diet throughout the rearing period and were individually weighed every two weeks (i.e. at 2, 4 and 6 weeks). At 6 weeks of age and after 7 hours feed withdrawal, all the birds were slaughtered at the experimental processing plant of the INRA Experimental Poultry Unit. Before sacrificing by ventral neck cutting, birds were electrically stunned $(125 \mathrm{~Hz} \mathrm{AC}, 80 \mathrm{~mA} / \mathrm{bird}, 5 \mathrm{~s})$ in a water bath, bled for $3 \mathrm{~min}$, and scalded at $51^{\circ} \mathrm{C}$ for $3 \mathrm{~min}$. After removal of the gut, whole carcasses were air chilled (airflow of $7 \mathrm{~m}^{3}$ ) and stored at $2{ }^{\circ} \mathrm{C}$ until the next day.

\section{Carcass and meat quality traits}

Breast muscle (Pectoralis major plus minor) and abdominal fat weights were measured after carcass dissection, 1 day post-slaughter. Corresponding ratios were calculated in relation to live body weight at 6 weeks. All measurements for meat characteristics were performed on the Pectoralis major muscle. The $\mathrm{pH}$ at $15 \mathrm{~min}$ and $24 \mathrm{~h}$ post mortem was measured with a portable $\mathrm{pH}$-meter (Model 506, Crison Instruments, SA, Spain) equipped with a xerolyte electrode. At $15 \mathrm{~min}$ post mortem, $\mathrm{pH}$ was estimated from $2 \mathrm{~g}$ of muscle mixed in $18 \mathrm{~mL}$ of a $5 \mathrm{mM}$ iodoacetate solution. This method was described as a reference method by Santé and Fernandez [22]. At 24 h post mortem, the ultimate $\mathrm{pH}$ of meat $\left(\mathrm{pH}_{\mathrm{u}}\right)$ was recorded by direct insertion of the xerolyte electrode in the muscle. This method was adopted because of the significant correlation obtained $24 \mathrm{~h}$ post mortem between the direct tissue measurement of $\mathrm{pH}$ and the reference "iodoacetate" method [22]. Breast meat color was measured at $24 \mathrm{~h}$ post-slaughter using a Miniscan Spectrocolorimeter with the CIE $\mathrm{L}^{*} \mathrm{a}^{*} \mathrm{~b}^{*}$ system, where $\mathrm{L}^{*}$ represents lightness, $\mathrm{a}^{*}$ redness and $\mathrm{b}^{*}$ yellowness. Higher $\mathrm{L}^{*}, \mathrm{a}^{*}$ and $\mathrm{b}^{*}$ values correspond to paler, redder and more yellow meat, respectively. The water-holding capacity of breast meat was estimated through drip loss (DL) measured after 2 days of storage of the fillet hung in a plastic bag and expressed as a percentage of the initial muscle weight. After DL measurement, P. major muscle was vacuum-packed and stored at $-25^{\circ} \mathrm{C}$. For meat texture analysis, breast muscle was thawed overnight at $4^{\circ} \mathrm{C}$, cooked in a water-bath at $85^{\circ} \mathrm{C}$ for $15 \mathrm{~min}$ to an internal endpoint temperature of $70^{\circ} \mathrm{C}$, and cooled in crushed ice for $20 \mathrm{~min}$. The thawing-cooking loss was expressed as a percentage of the fresh muscle weight. The toughness of cooked meat was evaluated by the Warner Bratzler (WB) shear test using an Instron Universal Testing Instrument.

\section{Muscle Parameters}

The P. major muscle glycogen, glucose-6-phosphate, free glucose and lactate concentrations (expressed in $\mu \mathrm{mol} / \mathrm{g}$ of muscle) were measured according to Dalrymple and 
Hamm [23] from $1 \mathrm{~g}$ of fresh tissue taken and homogenized in $10 \mathrm{ml}$ of 0.55 moles perchloric acid 15 min post mortem. Glycogen content available in breast muscle at slaughter time was estimated through the post mortem glycolytic potential (GP) according to the Monin and Sellier [24] equation:

$$
\begin{gathered}
\mathrm{GP}=2[(\text { glycogen })+(\text { glucose })+(\text { glucose- } 6-\text { phosphate })] \\
+(\text { lactate }) .
\end{gathered}
$$

GP was expressed as micromoles of lactate equivalent per gram of fresh tissue. The CSA of P. major muscle fibers was determined as described by Rémignon et al. [16] on 12 $\mu \mathrm{m}$-thick cross sections stained with red azurobin. Mean CSA was determined on approximately 300 fibers in 3 random fields for each muscle.

\section{Genetic Parameter Estimation}

Descriptive statistics for the different traits were calculated by the UNIVARIATE procedure of SAS software [25]. Genetic parameters were computed by VCE4 software using multivariate analysis and the REstricted Maximum Likelihood (REML) method [26]. The following linear mixed model was used:

$$
\mathbf{y}=\mathbf{X}_{1} \beta_{1}+\mathbf{X}_{2} \beta_{2}+\mathrm{Zu}+\varepsilon
$$

in which $y$ is the vector of performances observed, $\beta_{1}$ and $\beta_{2}$ the vectors of fixed effects for batch and sex, $\mathbf{u}$ the vector of genetic animal effects, and $\mathrm{e}$ the vector of residuals. $\mathrm{X}_{1}$, $\mathrm{X}_{2}$, and $\mathrm{Z}$ are the corresponding incidence matrices. As pedigree information was limited to the sires and dams of the birds measured for meat quality, the maternal environmental effects could not be correctly estimated in this genetic study. The analyses on growth performance excluded body weight measurements at the early ages of 2 and 4 weeks (which are known to be influenced by maternal effects) to focus on body weight at 6 weeks or weight gain expressed as the difference between body weight at 4 and 6 weeks.

\section{Authors' contributions}

EBD supervised the genetic analyses and drafted the manuscript. MD supervised the experimental design and performed the genetic analyses. CMB and VSL supervised the measurements of meat and muscle characteristics. EBD, $\mathrm{MD}, \mathrm{CMB}$, VSL, NS, and CB participated in the design of the study and data collection and helped to draft the manuscript. YJ supervised the breeding of the line and the production of the pedigree chicks used for this trial, and helped to draft the manuscript. All authors read and approved the final manuscript.

\section{Acknowledgements}

The authors thank the staff from the INRA experimental poultry unit (UE609 Unité Avicole, Nouzilly, France) for rearing the chickens. Measure- ments on the birds required the technical assistance of a large number of technicians, particularly Thierry Bordeau, Estelle Godet, Nicole Millet, and Axel Boucard (UR83 Recherches Avicoles, Nouzilly, France). We thank Hubbard (Chateaubourg, France) for providing the birds. This study was supported by grants from the French ACTA and Office de l'Elevage programs.

\section{References}

I. Sellier P: Genetics of meat and carcass traits. In The genetics of the pig Edited by: Rothschild MF, Ruvinsky A. CAB International, Cambridge (GBR); 1998:463-493.

2. Pietrzak M, Greaser ML, Sosnicki AA: Effect of Rapid Rigor Mortis Processes on Protein Functionality in Pectoralis Major Muscle of Domestic Turkeys. J Anim Sci 1997, 75:2 I06-2I I6.

3. Owens CM, Hirschler EM, McKee SR, Martinez-Dawson R, Sams AR: The characterization and incidence of pale, soft, exudative turkey meat in a commercial plant. Poult Sci 2000, 79:553-558.

4. Barbut S: Problem of pale soft exudative meat in broiler chickens. Br Poult Sci 1997, 38:355-358.

5. Allen CD, Russel SM, Fletcher DL: The Relationship of broiler breast meat color and $\mathrm{pH}$ to shelf-life and odor development. Poult Sci 1997, 76:1042-1046.

6. Otsu K, Khanna VK, Archibald AL, MacLennan DH: Cosegregation of porcine malignant hyperthermia and a probable causal mutation in the skeletal muscle ryanodine receptor gene in backcross families. Genomics 1991, I I:744-750.

7. Le Roy P, Naveau J, Elsen JM, Sellier P: Evidence for a new major gene influencing meat quality in pigs. Genet Res 1990, 55:33-40.

8. Milan D, Jeon J-T, Looft C, Amarger V, Robic A, Thelander M, RogelGaillard C, Paul S, lannucelli N, Rask L, Ronne H, Lundström K, Reinsch N, Gellin J, Kalm E, Le Roy P, Chardon P, Andersson L: A mutation in PRKAG3 associated with excess glycogen content in pig skeletal muscle. Science 2000, 288: |248-|25।.

9. Le Bihan-Duval $\mathrm{E}$, Millet N, Rémignon $\mathrm{H}$ : Broiler meat quality: effect of selection for increased carcass quality and estimates of genetic parameters. Poult Sci 1999, 78:822-826.

10. Le Bihan-Duval E, Berri C, Baéza E, Millet N, Beaumont C: Estimation of the genetic parameters of meat characteristics and of their genetic correlations with growth and body composition in an experimental broiler line. Poult Sci 200I, 80:839-843.

II. Le Bihan-Duval E, Berri C, Baéza E, Santé V, Astruc T, Rémignon H, Le Pottier G, Bentley J, Beaumont C, Fernandez X: Genetic parameters of meat technological quality traits in a grand-parental commercial line of turkey. Genet Sel Evol 2003, 35:623-635.

12. Oguz I, Aksit M, Önenc A, Gevrekci Y, Özdemir D, Altan Ö: Genetic variability of meat quality characteristics in Japanese quail (Coturnix coturnix japonica). Arch Geflügelk 2004, 68: I76-181.

13. Larzul C, Le Roy $P$, Monin G, Sellier P: Variabilité génétique du potentiel glycolytique du muscle chez le Porc. Inra Prod Anim 1998, I I:183-197.

14. Larzul C, Le Roy P, Gogué J, Talmant A, Jacquet B, Lefaucheur L, Ecolan $\mathrm{P}$, Sellier $\mathrm{P}$, Monin G: Selection for reduced muscle glycolytic potential in Large White pigs. II. Correlated responses in meat quality and muscle compositional traits. Genet Sel Evol 1999, $31: 61-76$

15. Berri C, Debut M, Santé-Lhoutellier V, Arnould C, Boutten B, Sellier $N$, Baéza $E$, Jehl N, Jégo $Y$, Duclos MJ, Le Bihan-Duval E: Variations in chicken breast meat quality: implications of struggle and muscle glycogen content at death. Br Poult Sci 2005, 46:572-579.

16. Rémignon H, Gardahaut MF, Marché G, Ricard FH: Selection for rapid growth increases the number and the size of muscle fibres without changing their typing in chickens. J Muscle Cell Motil 1995, 16:95-102.

17. Guernec A, Berri C, Chevalier B, Wacrenier-Céré N, Le Bihan-Duval $\mathrm{E}$, Duclos MJ: Muscle development, insulin-like growth factorI and myostatin mRNA levels in chickens selected for increased breast muscle yield. Growth Hormone and IGF Res 2003, 1 3:8-18.

18. Rehfeldt C, Fiedler I, Dietl G, Ender K: Myogenesis and postnatal skeletal muscle cell growth as influenced by selection. Livest Prod Sci 2000, 66: 177-188.

19. Berri C, Wacrenier N, Millet N, Le Bihan-Duval E: Effect of selection for improved body composition on muscle and meat 
characteristics of broilers from experimental and commercial lines. Poult Sci 200I, 80:833-838.

20. Nadaf J, Gilbert H, Pitel F, Berri CM, Feve K, Beaumont C, Duclos MJ, Vignal A, Porter TE, Simon J, Aggrey SE, Cogburn LA, Le Bihan-Duval $\mathrm{E}$ : Identification of QTL controlling meat quality traits in an $F 2$ cross between two chicken lines selected for either low or high growth rate. BMC Genomics 2007, 8: 155 .

21. Berri C, Le Bihan-Duval E, Debut M, Santé-Lhoutellier V, Baéza E, Gigaud V, Jégo Y, Duclos MJ: Consequence of muscle hypertrophy on characteristics of Pectoralis major muscle and breast meat quality of broiler chickens. J Anim Sci 2007, 85:2005-20II.

22. Santé $\mathrm{V}$, Fernandez $\mathrm{X}$ : The measurement of $\mathbf{p H}$ in raw and frozen turkey Pectoralis superficialis muscle. Meat Science 2000, 55:503-506.

23. Dalrymple RH, Hamm R: A method for extraction of glycogen and metabolites from a single muscle sample. J Food Technol 1973, 8:439-444.

24. Monin G, Sellier P: Pork of low technological quality with a normal rate of $\mathrm{pH}$ fall in the intermediate post-mortem period: The case of the Hampshire breed. Meat Sci 1985, 13:49-63.

25. SAS Institute: SAS Institute Inc., Cary, NC; 1999.

26. Neumaier A, Groeneveld E: Restricted maximum likelihood of covariances in sparse linear model. Genet Sel Evol 1998, 30:13-26.

Publish with Bio Med Central and every scientist can read your work free of charge

"BioMed Central will be the most significant development for disseminating the results of biomedical research in our lifetime. " Sir Paul Nurse, Cancer Research UK

Your research papers will be:

- available free of charge to the entire biomedical community

- peer reviewed and published immediately upon acceptance

- cited in PubMed and archived on PubMed Central

- yours - you keep the copyright

Submit your manuscript here:

http://www.biomedcentral.com/info/publishing_adv.asp
BioMedcentral 